\title{
Relationship between seasonal changes in spermatogenesis in the juvenile ostrich (Stuthio camelus) and the presence of the $\mathrm{LH}$ receptor and $3 \beta$-hydroxysteroid dehydrogenase
}

\author{
M-C. Madekurozwa ${ }^{1}$, T. S. Chabvepi ${ }^{1}$, S. Matema ${ }^{1}$ and K. J. Teerds ${ }^{2}$ \\ ${ }^{1}$ Department of Preclinical Veterinary Science, University of Zimbabwe, PO Box MP 167, \\ Mount Pleasant, Harare, Zimbabwe; and ${ }^{2}$ Department of Biochemistry and Cell Biology, \\ Utrecht University, PO Box 80176, 3508 TD Utrecht, The Netherlands
}

The immunohistochemical localization of the $\mathrm{LH}$ receptor

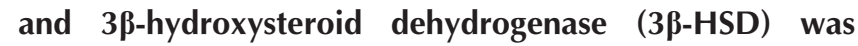
studied in the testis of the juvenile ostrich (Stuthio camelus) throughout a 1 year period. Spermatogenic activity of juvenile birds changed throughout the year, as has been reported previously for sexually mature birds. During the active stage of the testicular cycle, from September to January, spermatogenesis progressed up to the stage of formation of spermatozoa, although spermatozoa could not be detected in the epididymis. Leydig

\section{Introduction}

The ostrich (Struthio camelus) is considered to be a seasonal breeder. Several studies have indicated that the breeding season of this ratite bird depends on daylength and that testicular activity is restricted to a specific period of the year when daylength is long (Hicks, 1992; Mellet, 1993; Degen et al., 1994; Soley and Groenewald, 1999). The photodependency of the reproductive cycle of the ostrich was also observed under experimental conditions in which exposure to artificial light initiated the growth of the testes in adult ostriches (Jensen et al., 1992). However, it is necessary to consider that with an increase in daylength, there may also be an increase in food intake, which may also influence the onset of the breeding season (Sauer, 1972; Degen et al., 1994), as has been shown in another ratite species, the emu (Dromaius novaehollandiae; Blanche and Martin, 1999). Hence, the ostrich can be considered to be a photoperiod-dependent seasonal breeder, although it is possible that other factors, such as increased food intake as a result of increased daylength, also contribute to the initiation of the breeding season.

In avians, as in mammals, the testes are responsible for the production of spermatozoa and the secretion of androgens. Functional studies have identified the Leydig

Correspondence address: M-C Madekurozwa, c/o K. J. Teerds, Department of Biochemistry and Cell Biology, Faculty of Veterinary Medicine, Utrecht University, PO Box 80176, 3508 TD Utrecht, The Netherlands

Email:k.j.teerds@vet.uu.nl cells stained intensely with antibodies against the LH

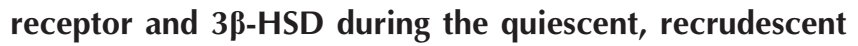
and active phases of the testicular cycle. During the regressive phase, there was a slight decrease in immunostaining for $3 \beta-\mathrm{HSD}$ in these cells. These results indicate that Leydig cells in the testis of the juvenile ostrich are able to respond to LH and are capable of steroid synthesis. Furthermore, in juvenile (prepubertal) ostriches, spermatogeneic activity can be observed and, as in mature birds, spermatogenesis undergoes seasonal changes.

cells as the site of androgen production in a variety of birds, including the domestic fowl, Gallus domesticus (Woods and Domm, 1966; Galli et al., 1973; Rosenstrauch et al., 1998), the spur-winged goose, Plectropterus gambensis (Halse, 1985), the brown-headed cowbird, Molothrus ater (Dufty and Wingfield, 1986), the Japanese quail, Coturnix coturnix japonica (Nicholls and Graham, 1972) and the king penguin, Aptenodytes patagonicus (Mauget et al., 1994). In mammals, the production of the androgens, androstenedione and testosterone, from dehydroepiandrosterone and androstenediol, respectively, is catalysed by $3 \beta$ hydroxysteroid dehydrogenase ( $3 \beta-\mathrm{HSD})$, a marker enzyme for the Leydig cells (Lorence et al., 1990; Majdic et al., 1998). In birds, very little is known about the localization of $3 \beta$-HSD in the testis. Freking et al. (2000) demonstrated the expression of this steroidogenic enzyme in the interstitial compartment of the zebra finch testis, but they were unable to identify the positive cells.

Steroidogenesis in Leydig cells is regulated by LH, secreted by the pituitary gland (Brown et al., 1975). In birds, as in mammals, it has been demonstrated that changes in plasma concentrations of $\mathrm{LH}$ coincide with changes in testosterone concentrations (Schmidt et al., 1991; Degen et al., 1994; Fowler et al., 1994; Jacquet and Sauveur, 1995). These functional studies indicate that the Leydig cells in the avian testis possess LH receptors and 33-HSD activity, although this finding has not been confirmed at the protein level. Hence, the objective of the present study was to investigate the immunohistochemical localization of the $\mathrm{LH}$ receptor and $3 \beta-\mathrm{HSD}$ in relation to seasonal changes in testicular morphology in the juvenile ostrich. 


\section{Materials and Methods}

\section{Animals}

Juvenile male ostriches used in this study originated from commercial farms in the Mashonaland province of Zimbabwe $\left(18^{\circ} \mathrm{S}\right)$. This is a sub-tropical region with daylengths varying from $13.01 \mathrm{~h}$ of light at the summer solstice (from the end of December to March) to $10.80 \mathrm{~h}$ of light at the winter solstice (from the end of June to September). The eggs from which these birds hatched were laid between July and February. The birds had been fed commercially produced food throughout the rearing period. In addition, lucerne and water had been provided ad libitum.

Testes were obtained from juvenile ostriches at an abattoir. Samples were collected from 15 birds each month for 1 year. The birds were 9-12 months of age when they were killed and their body weights were 90-100 kg.

\section{Histology}

Testicular and epididymal tissues were immersed in Bouin's fixative for $48 \mathrm{~h}$. After the tissues were fixed, they were dehydrated through graded concentrations of ethanol and embedded in paraffin wax. For each animal, five testicular tissue blocks were chosen at random and investigated in more detail. From each block of tissue, ten sections of $5 \mu \mathrm{m}$ in thickness were cut, at least $200 \mu \mathrm{m}$ apart, and studied after staining with Mayer's haematoxylin and eosin.

Changes in seminiferous tubule architecture of juvenile ostriches were investigated throughout the seasons, using the method of Halse (1985) for the spur-winged goose. Briefly, the diameters of ten seminiferous tubules were measured per section and the mean tubular diameter was calculated. The diameters of circular tubular cross-sections were measured twice, at right angles. For each animal, five sections from five different tissue blocks were analysed using the same method. The thickness of the seminiferous epithelium was estimated in ten tubules per section, and was measured from the basal membrane towards the lumen of the tubule. In each tubular cross-section, the height of the epithelium was measured four times at right angles. For each animal, these separate measurements were repeated in at least five sections from five different tissue blocks, using an ocular micrometer. In this way, mean epithelial values obtained were compared with changes in daylength.

In the same sections, the size of the interstitial areas was estimated according to the methods of Halse (1985). Briefly, the width of the interstitial tissue was measured at the narrowest point between two seminiferous tubules using an ocular micrometer. For each section, ten interstitial areas were measured using this method and a mean value was calculated. For each animal, five sections from five different tissue blocks were analysed using this method.

In addition, five epididymal tissue blocks from each bird were chosen at random and investigated in more detail. From each block, five sections were cut at least $200 \mu \mathrm{m}$ apart and studied after staining with haematoxylin and eosin. In each tissue section, ten cross-sections through the ductus epididymidis were investigated for the presence of spermatozoa.

\section{Statistical analysis}

Statistical differences were evaluated by ANOVA and the Turkey-Kramer multiple comparisons test. Values were considered to be significantly different at $P<0.05$.

\section{Antibodies}

The $\mathrm{LH}$ receptor monoclonal antibody (P1B4) was a gift from J. Wimalasena (University of Tennessee, Knoxville, $\mathrm{TN})$. This antibody was raised against the purified rat $\mathrm{LH}$ receptor, as described by Indrapichate et al. (1992), and has been shown to bind specifically to $\mathrm{LH}$ receptors in rat gonads (Bukovsky et al., 1993; Teerds and Dorrington, 1995; Majdic et al., 1998). A biotinylated goat anti-mouse IgG was used as a secondary antibody (Vector stain kit elite, Vector Laboratories, Burlingame, CA).

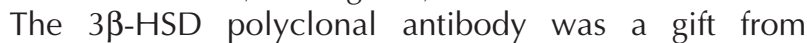
V. Luu-The (Laval University, Quebec, PQ). This antibody was obtained after immunization of rabbits with $3 \beta-H S D$ purified from human placenta (Luu-The et al., 1989). This antibody has been used for the localization of $3 \beta-H S D$ in the human placenta and ovary, as well as in guinea-pig and rat gonads and adrenal glands (Luu-The et al., 1989; Dupont et al., 1990a,b, 1992; Teerds and Dorrington, 1993; Madjic et al., 1998). A biotinylated goat anti-rabbit IgG was used as a secondary antibody (Vector Labs).

\section{Immunohistochemical staining}

The immunostaining technique was performed on sections of $5 \mu \mathrm{m}$ thickness according to methods described previously (Teerds and Dorrington, 1993, 1995; Majdec et al., 1998; Teerds et al., 1999). Sections from ten birds for each group were used for the immunohistochemical detection of the LH receptor and $3 \beta-\mathrm{HSD}$. Briefly, paraffin wax was removed from the sections and endogenous peroxidase activity was blocked with $3 \%(v / v) \mathrm{H}_{2} \mathrm{O}_{2}$ in methanol for $30 \mathrm{~min}$. The slides were then washed in a $0.01 \mathrm{~mol}$ Tris-buffered saline (TBS) solution $\mathrm{I}^{-1}(\mathrm{pH} 7.4)$, incubated with 0.1 mol glycine $\mathrm{I}^{-1}$ in TBS for 30 min and then rinsed in TBS. This was followed by a blocking step with $5 \%$ normal goat serum for 30 min. The slides were incubated overnight at $4{ }^{\circ} \mathrm{C}$ in a humidified chamber with antibodies against the $\mathrm{LH}$ receptor and $3 \beta-\mathrm{HSD}$, at a dilution of $1: 5000$ and 1:300, respectively, in TBS with $0.05 \%$ acetylated BSA (Aurion, Wageningen) and then rinsed in TBS. The slides treated with the $\mathrm{LH}$ receptor antibody were incubated for $60 \mathrm{~min}$ with a biotinylated goat anti-mouse IgG, diluted 1:200 in TBS containing $0.05 \%$ acetylated BSA. The slides treated with the $3 \beta-\mathrm{HSD}$ antibody were incubated for $60 \mathrm{~min}$ with a biotinylated goat anti-rabbit IgG diluted 1:100 in TBS containing $0.05 \%$ acetylated BSA. Both incubations were carried out at room 

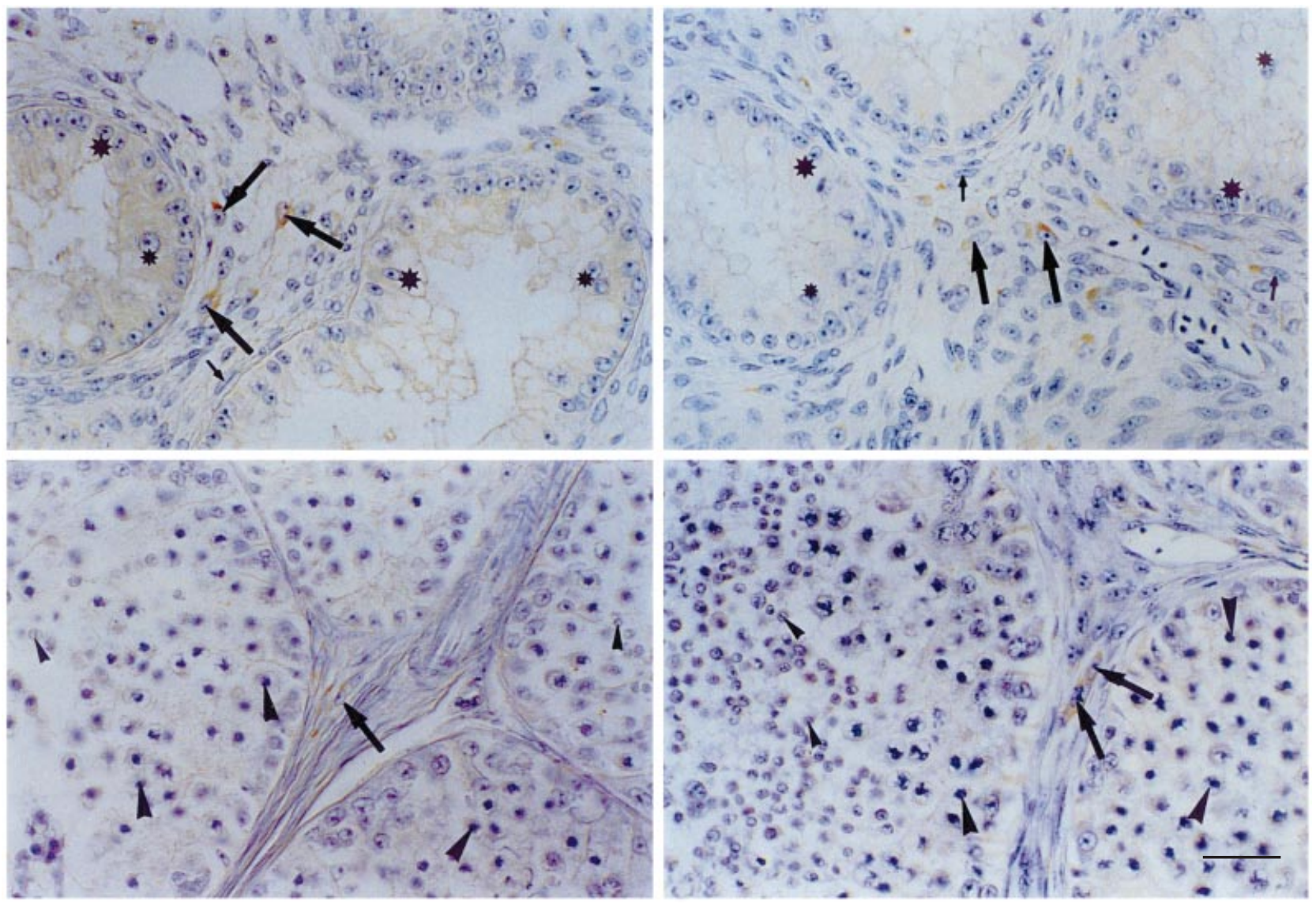

Fig. 1. Immunohistochemical localization of $(a, c) 3 \beta$-hydroxysteroid dehydrogenase $(3 \beta-H S D)$ and $(b, d)$ the $\mathrm{LH}$ receptor in the testis of the juvenile ostrich. During the quiescent phase $(a, b)$ of the reproductive cycle, brown stained (immunopositive) Leydig cells with round to oval nuclei (large arrows) were located in the wide interstitial areas between the seminiferous tubules. Within the seminiferous tubules, only Sertoli cells (large asterisks) and spermatogonia (small asterisks) were present. The recrudescent stage $(\mathrm{c}, \mathrm{d})$ was marked by the presence of primary spermatocytes (large arrowheads) and round spermatids (small arrowheads) in the seminiferous tubules. Fibroblast-like Leydig precursor cells are indicated by small arrows. Scale bar represents $23 \mu \mathrm{m}$.

temperature. The slides were then rinsed in TBS and incubated for $60 \mathrm{~min}$ at room temperature with the components avidin $(A)$ and biotin $(B)$ from the $A B C$ staining kit. Both components (A and B) were diluted (1:3000) and prepared at least $15 \mathrm{~min}$ before addition to the sections. The slides were then rinsed in TBS and 0.05 mol Tris- $-\mathrm{HCl} \mathrm{I}^{-1}$ $(\mathrm{pH}$ 7.6). Bound antibody was visualized by the addition of a $0.06 \mathrm{mg} \mathrm{ml}^{-1}$ solution of 3,3'-diaminobenzidine tetrachloride (Sigma-Aldrich, Deisenhofen) in $0.05 \mathrm{~mol}$ Tris- $\mathrm{HCl} \mathrm{I-1}$, to which $0.03 \% \mathrm{H}_{2} \mathrm{O}_{2}$ was added. Slides were counterstained with Mayer's haematoxylin.

Two types of controls were included during the immunohistochemical incubation procedures. In the first type of control incubation, normal rabbit and mouse sera were used instead of the $3 \beta-\mathrm{HSD}$ and LH receptor antibodies, respectively. In the second type of control incubation, rat testicular sections were incubated with $3 \beta-\mathrm{HSD}$ and LH receptor antibodies to demonstrate that the same type of cell was recognized by the antibodies in the ostrich testis as in the rat testis.

\section{Results}

On the basis of seasonal changes in testicular morphology, the reproductive cycle of the juvenile ostriches could be divided into four phases: (i) a quiescent phase from April to June when daylength is decreasing; (ii) a recrudescent phase in July and August during the winter when daylength is short; (iii) an active phase from September to January when daylength increases; and (iv) a regressive phase in February and March when daylength starts to decrease again. Testicular morphology changed markedly throughout the reproductive cycle, with only a single layer of Sertoli cells and spermatogonia present at the quiescent phase and a full complement of germ cells during the active phase. In the quiescent period, positive immunohistochemical staining for the LH receptor (Fig. 1a) and for 3 3 -HSD (Fig. 1b) was evident in the Leydig cells located in the wide interstitial areas between the seminiferous tubules. These positively stained Leydig cells were recognized by their oval to spherical nuclei and the presence of one or two prominent, 


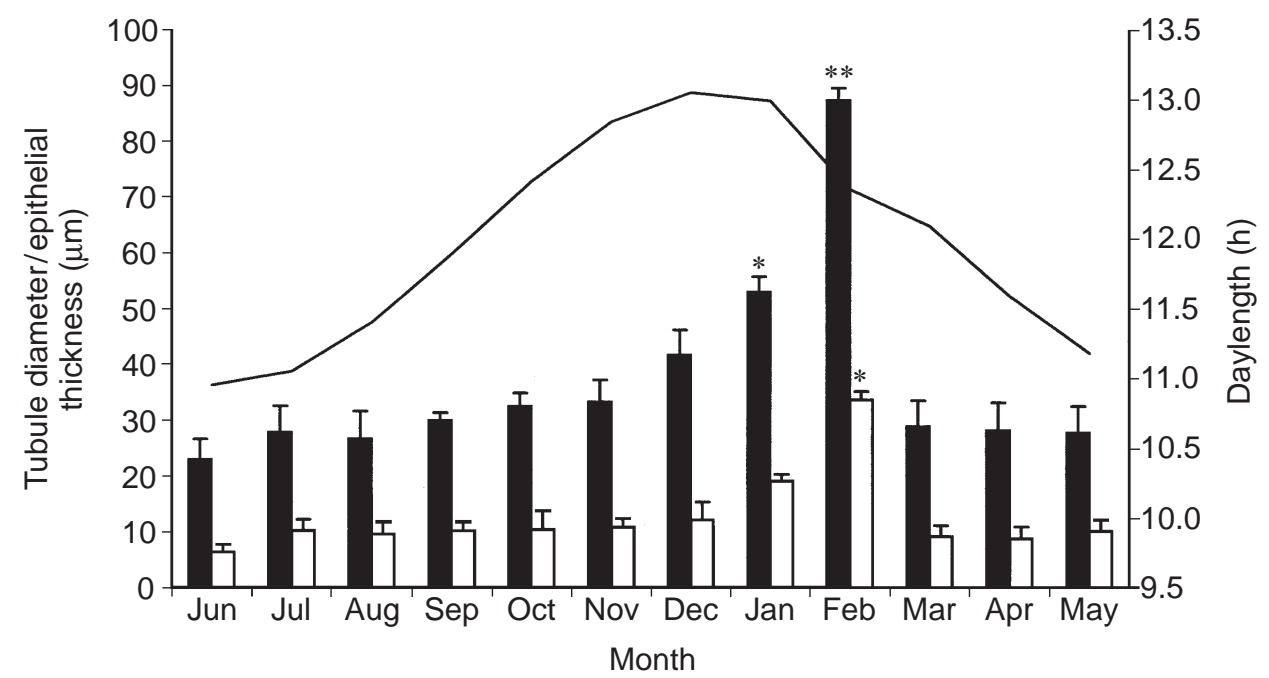

Fig. 2. Seasonal changes in the diameter of seminiferous tubules ( $\boldsymbol{\square})$ and the thickness of the seminiferous epithelium $(\square)$ in the juvenile ostrich testis. The summer season starts at the end of December and lasts until March; autumn begins in March and lasts until June; winter starts at the end of June and lasts until September, and spring starts at the end of September and lasts until December. All values are expressed as means \pm SEM. The line indicates the mean daylength. In January and February the mean diameter of the seminiferous tubules and in February the mean thickness of the seminiferous epithelium are significantly increased compared with the other months $\left({ }^{*} P<0.05 ; * * P<0.01\right)$.

round nucleoli. The same type of cell stained positively with both antibodies in the rat testis (data not shown; Majdic et al., 1998, Teerds et al., 1999).

Recrudescence of the testes in July and August was marked by the appearance of primary spermatocytes and round spermatids within the seminiferous tubules. Leydig cells that stained positively with the antibodies against the $\mathrm{LH}$ receptor (Fig. 1c) and $3 \beta-\mathrm{HSD}$ (Fig. 1d) were present within the interstitial compartment.

During the active phase, from September to January, and the early regressive phase, which started in February, the diameter of the seminiferous tubules increased progressively (Fig. 2). The thickness of the seminiferous epithelium had a tendency to increase during the active phase and was significantly increased during the early regressive phase. The active phase was characterized by the presence of a full complement of spermatogenic cells, ranging from spermatogonia, spermatocytes, spermatids to spermatozoa. As a consequence of the increase in diameter of the seminiferous tubules, the interstitial space seemed to be reduced in size. Leydig cells that stained positively with the antibodies against the $\mathrm{LH}$ receptor (Fig. $3 \mathrm{a}$ ) and $3 \beta-\mathrm{HSD}$ (Fig. 3b) were distributed sparsely between the enlarged seminiferous tubules.

The presence of degenerating spermatogenic cells was characteristic of the regressive phase in February and March. During this period the cytoplasmic bridges between the degenerating germ cells enlarged, resulting in the formation of multi-nucleated giant cells. Apoptotic spermatid nuclei were also observed (Fig. 3c,d). Healthy and slightly apoptotic Leydig cells stained positively with the antibodies against the LH receptor (Fig. 3c) and 3ß-HSD (Fig. 3d). Nevertheless, it appeared that not all Leydig cells expressed immunoreactivity. The intensity of the staining for $3 \beta-H S D$ was slightly less than that observed during the other phases of the reproductive cycle. In addition to the Leydig cells, numerous fibroblast-like cells with elongated nuclei, which are presumed to be the precursors of the Leydig cells, were present in the interstitium (Fig. 3c,d). Background staining was negligible in the control slides that were incubated with normal serum instead of the primary antibody. Representative sections are shown (Fig. 3e,f).

\section{Epididymis}

Throughout the year, the epididymal tubules were lined with a simple cuboidal epithelium. Although spermatozoa were observed within the seminiferous tubules during the active and early regressive phases of the reproductive cycle, spermatozoa were not observed in the epididymis of any of these juvenile birds, regardless of the part of the epididymis studied (data not shown).

\section{Correlation between daylength and histological characteristics}

There was a positive correlation between daylength and the diameter of the seminiferous tubule $(r=0.92$; $P<0.0001)$, and between daylength and the thickness of the seminiferous epithelium $(r=0.75 ; P<0.005)$. There was a negative correlation between daylength and the size of the interstitial areas located between the tubules $(r=-0.70 ; P<0.01)$. 

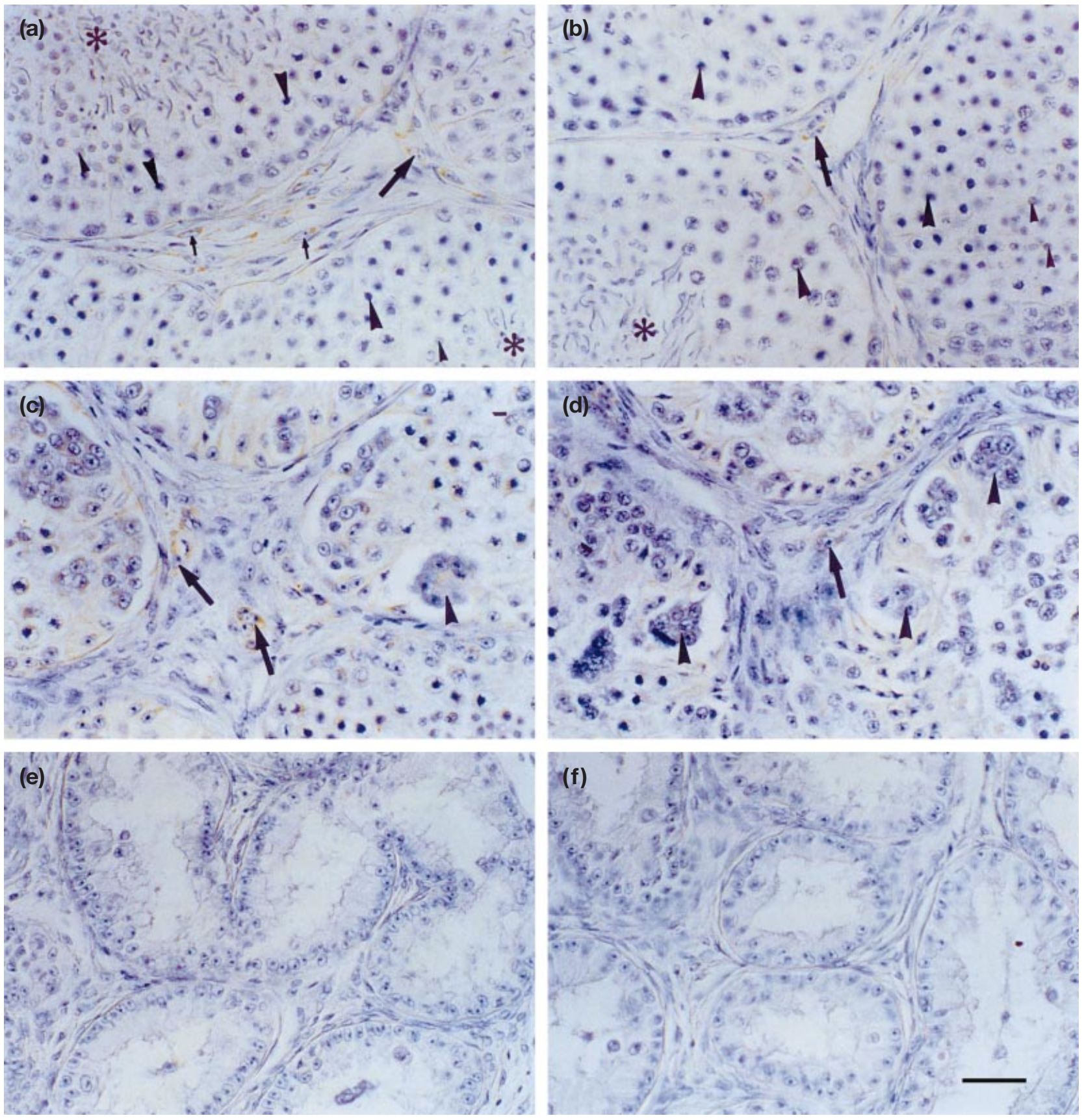

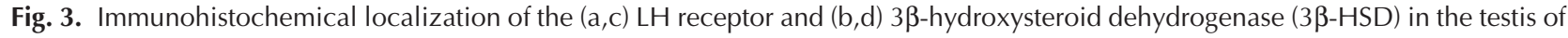
the juvenile ostrich. During the active phase of the reproductive cycle $(a, b)$ spermatocytes (large arrowheads), round spermatids (small arrowheads) and spermatozoa (asterisks) could be observed in the seminiferous tubules. Brown stained (immunopositive) Leydig cells are indicated by large arrows. During the regressive period (c,d), degenerating germ cells changed into multinucleated giant cells (large arrowheads). In the nuclei of some Leydig cells, condensation of the heterochromatin was observed indicative of apoptosis (large arrows). Small arrows indicate presumptive Leydig precursor cells with elongated nuclei. (e,f) No immunostaining was found in control sections incubated with either (e) normal mouse or (f) normal rabbit sera, instead of primary antibody. Scale bar represents $23 \mu \mathrm{m}$.

\section{Discussion}

The present study has established that the testes of the juvenile ostrich undergo seasonal changes. There are indications that these changes in spermatogenic acitivity are related to variations in photoperiod, although at this stage other factors, such as increased food intake as a consequence of increasing daylength, may also positively influence the initiation of reproductive activity. The quiescent phase of the testicular cycle in the juvenile 
ostriches extended from April to June, a period marked by short daylengths. In the inactive testis, the seminiferous tubules contained only Sertoli cells and spermatogonia. A period of testicular inactivity has also been observed in adults of other avian species, such as the Japanese quail, Coturnix coturnix japonica (Follett and Maung, 1978; Baraldi Artoni et al., 1997, 1999) and the Canadian goose, Branta canadensis (John et al., 1983). In these two species, testicular inactivity was related to low circulating concentrations of gonadotrophins, due to reduced stimulation of the hypothalamic-pituitary-gonadal axis.

The androgen-producing Leydig cells were located in the wide interstitial spaces between the inactive seminiferous tubules, an observation comparable to that reported in the Canadian goose (John et al., 1983) and the Japanese quail (Aire, 1997). In ostriches, the Leydig cells specifically bound antibodies raised against the $\mathrm{LH}$ receptor and $3 \beta$ HSD. This finding indicates that even in the inactive testis of the juvenile ostrich, Leydig cells have the capacity to produce steroids.

Spermatogenesis in the juvenile ostrich was initiated in July and August, as daylength started to increase. In the starling, Sturnus vulgaris (Williams et al., 1987a,b; Dawson and Goldsmith, 1989; McNaughton et al., 1992), the Muscovy duck, Cairina moschata (Jacquet and Sauveur, 1995) and the great tit, Parus major (Silverin and Sharp, 1996), photoperiod-refractoriness was dissipated by short daylengths. As a result, the hypothalamic-pituitary-gonadal axis was able to respond to increasing daylengths with the progression of the season, resulting in the initiation of spermatogenesis. Whether photoperiod-refractoriness also plays a role in juvenile ostriches is not clear.

Testicular recrudescence in the juvenile ostrich was marked by the appearance of primary spermatocytes and round spermatids in the seminiferous tubules. As the seminiferous tubules enlarged progressively from the end of the recrudescent phase to the active phase, the interstitial space became reduced in size. The Leydig cells, which stained positively for $3 \beta-\mathrm{HSD}$ and the $\mathrm{LH}$ receptor, became distributed sparsely in the narrow interstitial areas between the tubules. Similar morphological changes were observed in the testes of the white-crowned sparrow, Zonotrichia leucophyrs gambelii (Lam and Farner, 1976) and the Japanese quail (Aire, 1997; Baraldi Artoni et al., 1997, 1999). In birds, as in mammals, the steroidogenic activity of Leydig cells is stimulated by $\mathrm{LH}$, resulting in an increase in testosterone production (Lam and Farner, 1976; Schmidt et al., 1991; Mauget et al., 1994). Testosterone together with $\mathrm{FSH}$ is essential for the qualitative and quantitative progression of the process of spermatogenesis (for a review, see Sharpe, 1994).

Although spermatozoa were observed in the seminiferous tubules during the active phase in the present study, no spermatozoa were found in the epididymis. This finding may indicate that spermiation had not yet occurred in the juvenile ostrich testis and that the spermatozoa were not released from the seminiferous epithelium but were phagocytosed, presumably by the Sertoli cells. An alternative explanation could be that although spermiation and subsequent transport of the spermatozoa occurred, these cells underwent degeneration before they reached the epididymis and were subsequently phagocytosed by the epithelial cells lining the rete testis or ductuli efferentes. A detailed morphological analysis of the rete testis and ductuli efferentes may give more information about the fate of spermatozoa.

Male ostriches become sexually mature at about 2-3 years of age (Jensen et al., 1992). Therefore, it was surprising to observe that spermatogenesis was initiated in a seasonally dependent manner in the juvenile ostrich, long before the birds have reached sexual maturity. Whether this is a normal occurrence in ratite birds is not known.

As daylength decreased in February, the testes entered the regressive phase, during which apoptotic germ cells could be observed in the seminiferous tubules. As indicated previously, the amount of $\mathrm{GnRH}$ secreted by the hypothalamus is dependent on daylength. Therefore, it was hypothesized that a decrease in $\mathrm{GnRH}$ secretion as a consequence of the reduction in daylength and the subsequent decrease in $\mathrm{LH}$ and testosterone production (Degen et al., 1994) may be responsible for the cessation of spermatogenesis. Nevertheless, additional experiments need to be carried out in which plasma concentrations of $\mathrm{LH}$ and testosterone are measured in these birds throughout the year. Similar effects of decreased gonadotrophin production and subsequent reduction in testosterone synthesis have been observed in rats (Bartlett et al., 1986; Kerr et al., 1993; Woolveridge et al., 1999).

The slight decrease in staining intensity for $3 \beta-\mathrm{HSD}$ in Leydig cells during the regressive phase was possibly due to degeneration of the Leydig cell population. Apoptotic Leydig cells were observed occasionally. Degeneration of the Leydig cell population has also been observed during the regressive phase in the testis of the white-crowned sparrow (Lam and Farner, 1976).

Generally, during the recrudescence phase, degenerated Leydig cells were replaced by immature Leydig cells that had differentiated from fibroblast-like, precursor Leydig cells (Nicholls and Graham, 1972; Teerds et al., 1987, 1989a, 1992). Indeed, cells with a fibroblast-like morphology, assumed to be Leydig cell precursors, were observed in the juvenile ostrich testes during the recrudescent, quiescent and regressive phases of the testicular cycle. On the basis of data available for rats (Hardy et al., 1989; Teerds et al., 1989b), it is probable that in the juvenile ostrich these precursor cells are also able to proliferate and differentiate into Leydig cells in the presence of low LH concentrations, characteristic of the regressive and quiescent phase of the reproductive cycle (Degen et al., 1994).

In conclusion, the results of the present study indicate that spermatogenesis is already initiated in juvenile ostriches. Moreover, spermatogenic activity seems to undergo seasonal changes, which is presumably related to changes in daylength. This annual reproductive cycle 
results in the production of semen containing spermatozoa, although transport of these sperm cells may be affected, as indicated by the lack of spermatozoa in the epididymis. In addition, the present study has shown that in the juvenile ostrich testis, Leydig cells possess $\mathrm{LH}$ receptors and the steroidogenic enzyme $3 \beta-H S D$ during the quiescent, recrudescent, active and regressive phases of the testicular cycle, indicating that these cells are capable of steroid production. It may be possible that even in juvenile birds, the hypothalamic-pituitary-gonadal axis is responsive to photoperiod stimulation. However, before firm conclusions can be drawn, results of studies currently investigating plasma concentrations of gonadotrophins and testosterone throughout the annual testicular cycle are required.

The authors wish to thank M. de Boer-Brouwer, P. Mtombeni and B. Ndoro for their technical assistance, and $\mathrm{H}$. Halsema for preparing the photomicrograph plates. The authors extend their thanks to the management and staff of COPRO (Norton, Zimbabwe) for their cooperation and assistance. Financial support by the European Union, under the Utrecht University-University of Zimbabwe collaborative research link UZ-UU-KVL2000 link project 7ZIM039, is gratefully acknowledged.

\section{References}

Aire TA (1997) The structure of the interstitial tissue of the active and resting avian testis Onderstepoort Journal of Veterinary Research 64 291-299

Baraldi ASM, Orsi AM, Carvalho TLL and Lopes RA (1997) The annual testicular cycle of the domestic quail (Coturnix coturnix japonica) testis Anatomy, Histology and Embryology 28 217-220

Baraldi Artoni SM, Orsi AM, Carvalho TLL, Vicentini CA and Stefanini MA (1999) Seasonal morphology of the domestic quail (Coturnix coturnix japonica) testis Anatomy, Histology and Embryology 28 217-220

Bartlett JMS, Kerr JB and Sharpe RM (1986) The effect of selective destruction and regeneration of rat Leydig cells on the intratesticular distribution of testosterone and morphology of the seminiferous epithelium Journal of Andrology 7 240-253

Blanche D and Martin GB (1999) Daylength affects feeding behaviour and food intake in adult male emus (Dromaius novaehollandiae) British Poultry Science 40 573-578

Brown NL, Bayle JD, Scanes CG and Follett BK (1975) Chicken gonadotrophins: their effects on the testis of immature and hypophysectomized Japanese quail Cell and Tissue Research 156 499-520

Bukovsky A, Chen TT, Wimalasena J and Caudle MR (1993) Cellular localization of $\mathrm{LH}$ receptor immunoreactivity in the ovaries of immature, gonadotropin-primed and normal cycling rats Biology of Reproduction 48 1367-1382

Dawson A and Goldsmith AR (1983) Plasma prolactin and gonadotrophins during gonadal development and the onset of photorefractoriness in male and female starlings (Sturnus vulgaris) on artificial photoperiods Journal of Endocrinology 97 253-260

Degen AA, Weil S, Rosenstrauch A, Kam M and Dawson A (1994) Seasonal plasma levels of luteinizing and steroid hormones in male and female domestic ostriches (Struthio camelus) General and Comparative Endocrinology 93 21-27

Dufty AM and Wingfield JC (1986) Temporal patterns of circulating LH and steroid hormones in a brood parasite, the brown-headed cowbird, Molothrus ater. Journal of Zoology (London) 208 191-203

Dupont E, Luu-The V, Labrie F and Pelletier G (1990a) Light microscopic immunocytochemical localization of 3ß-hydroxy-5-ene-steroid dehydrogenase/ $\Delta 5-\Delta 4$-isomerase in the gonads and adrenal glands of the guinea-pig Endocrinology 126 2906-2909

Dupont E, Zhao HF, Rheaume E, Simard J, Luu-The V and Pelleteir G (1990b) Localization of $3 \beta$-hydroxysteroid dehydrogenase/ $\Delta 5-\Delta 4$ isomerase in rat gonads and adrenal glands by immunocytochemistry and in situ hybridization Endocrinology 127 1394-1403

Dupont E, Labrie F, Luu-The V and Pelletier G (1992) Immunocytochemical localization of $3 \beta$-hydroxysteroid dehydrogenase/ $\Delta 5-\Delta 4$-isomerase in human ovary Journal of Clinical Endocrinology and Metabolism $\mathbf{7 4}$ 994-998

Follett BK and Maung SL (1978) Rate of testicular maturation in relation to gonadotrophin and testosterone levels, in quail exposed to various artificial photoperiods and to natural daylengths Journal of Endocrinology 78 267-280

Fowler GS, Wingfield JC, Boersma PD and Sosa RA (1994) Reproductive endocrinology and weight changes in relation to reproductive success in the magellanic penguin (Spheniscus magellanicus) General and Comparative Endocrinology 94 305-315

Freking F, Nazairians T and Schlinger BA (2000) The expression of the sex steroid-synthesizing enzymes CYP11A1, 3ß-HSD, CYP17 and CYP19 in gonads and adrenals of adult developing zebra finches General and Comparative Endocrinology 119 140-151

Galli FE, Irusta O and Wassermann GF (1973) Androgen production by testes of Gallus domesticus during postembryonic development General and Comparative Endocrinology $21262-266$

Halse SA (1985) Gonadal cycles and levels of LH in wild spur-winged geese, Plectropterus gambensis. Journal of Zoology (London) 205 335-355

Hardy MP, Zirkin BR and Ewing LL (1989) Kinetic studies on the development of the adult population of Leydig cells in testis of the prepubertal rat Endocrinology 124 762-770

Hicks KD (1992) Ratite reproduction Proceedings of Association of Avian Veterinarians 318-325

Indrapichate K, Meehan D, Lane TA, Chu SY, Rao Ch V, Johnson D, Chen TT and Wimalasena J (1992) Biological actions of monoclonal luteinizing hormone/human chorionic gonadotropin receptor antibodies Biology of Reproduction 52 500-508

Jacquet JM and Sauveur B (1995) Photoperiodic control of sexual maturation in muscovy drakes Domestic Animal Endocrinology 12 189-195

Jensen J, Johnson JH and Weiner ST (1992) Reproduction. In Husbandry and Medical Management of Ostriches, Emus and Rheas pp 37-60 Wildlife and Exotic Animal TeleConsultants

John TM, George JC and Scanes CG (1983) Seasonal changes in circulating levels of luteinizing hormone and growth hormone in the migratory Canada goose General and Comparative Endocrinology 51 44-49

Kerr JB, Millar M, Maddocks S and Sharpe RM (1993) Stage-dependent changes in spermatogenesis and Sertoli cells in relation to the onset of spermatogenic failure following withdrawal of testosterone The Anatomical Record 235 547-559

Lam F and Farner DS (1976) The ultrastructure of the cells of Leydig in the white-crowned sparrow (Zonotrichia leucophrys gambelii) in relation to plasma levels of LH and testosterone Cell and Tissue Research 169 93-109

Lorence MC, Murry BA, Trant JM and Mason JL (1990) Human 3ß-hydroxysteroid dehydrogenase $\Delta(5)-\Delta(4)$-isomerase from placenta: expression in non-steroidogenic cells of a protein that catalyses the dehydrogenation/ isomerization of C21 and C19 steroids Endocrinology 126 2493-2498

Luu-The V, Lachance Y, Labrie C, Leblanc G, Thomas JL, Strickler RC and Labrie F (1989) Full length cDNA structure and deduced amino acid sequence of human 3 3 -hydroxy-5-ene-steroid dehydrogenase Molecular Endocrinology 3 1310-1319

McNaughton FJ, Dawson A and Goldsmith AR (1992) Puberty in birds: the reproductive system of starlings does not respond to short days until the birds are fully grown Journal of Endocrinology 132 411-417

Majdic G, Saunders PTK and Teerds KJ (1998) Immunoexpression of the steroidogenic enzymes $3 \beta$-hydroxysteroid dehydrogenase and $17 \alpha$ hydroxylase, $\mathrm{C} 17,20$ lyase and the receptor for $\mathrm{LH}$ in the fetal rat testis suggests that the onset of Leydig cell steroid production is independent of $\mathrm{LH}$ action Biology of Reproduction 58 520-525

Mauget R, Jouventin P, Lacroix A and Ishii S (1994) Plasma LH and steroid hormones in king penguin (Aptenodytes patagonicus) during the onset of the breeding cycle General and Comparative Endocrinology 93 $36-43$ 
Mellet FD (1993) Ostrich production and products. In Livestock Production Systems, Principles and Practice pp 187-194 Eds C Maree and NH Casey. Agri Development Foundation, Pretoria

Nicholls TJ and Graham GP (1972) Observations on the ultrastructure and differentiation of Leydig cells in the testis of the Japanese quail Biology of Reproduction 6 179-192

Rosenstrauch A, Weil S, Degen AA and Friedlander M (1998) Leydig cell functional structure and plasma androgen level during the decline in fertility in aging roosters General and Comparative Endocrinology 109 251-258

Sauer EGF (1972) Aberrant sexual behaviour in the South African ostrich Auk $89717-737$

Schmidt LG, Bradshaw SD and Follett BK (1991) Plasma levels of LH and androgens in relation to age and breeding status among cooperatively breeding Australian magpies (Gymnorhina tibicen latham) General and Comparative Endocrinology 83 48-55

Sharpe RM (1994) Regulation of spermatogenesis. In The Physiology of Reproduction Vol. 1 pp 1363-1434 Eds E Knobil and JD Neill. Raven Press, New York

Silverin B and Sharp P (1996) The development of the hypothalamicpituitary-gonadal axis in juvenile great tits General and Comparative Endocrinology 103 150-166

Soley JT and Groenewald HB (1999) Reproduction. In The Ostrich, Biology, Production and Health pp 144-145 Ed. DC Deeming. CABI Publishing, New York

Teerds KJ and Dorrington JH (1993) Immunohistochemical localization of $3 \beta$-hydroxysteroid dehydrogenase in the rat ovary during follicular development and atresia Biology of Reproduction 49 989-996

Teerds KJ and Dorrington JH (1995) Immunohistochemical localization of transforming growth factor $\alpha$ and luteinizing hormone receptor in healthy and atretic follicles of the adult rat Biology of Reproduction 52 500-508

Teerds KJ, de Rooij DG, Rommerts FFG and Wensing CJG (1987) Proliferation and differentiation of Leydig cells in the rat testis Annals of the New York Academy of Sciences 513 344-346

Teerds KJ, Rommerts FFG, Van de Kant HJG and Wensing CJG (1989a)
Leydig cell number and function in the adult cynomolgus monkey (Macaca fascicularis) is increased by daily hCG treatment but not by daily FSH treatment Journal of Reproduction and Fertility 87 141-146

Teerds KJ, de Rooij DG, Rommerts FFG, van den Hurk $R$ and Wensing CJG (1989b) Stimulation of the proliferation and differentiation of Leydig cell precursors after the destruction of existing Leydig cells with ethane dimethyl sulphonate (EDS) can take place in the absence of LH Journal of Andrology $10472-477$

Teerds KJ, de Rooij DG, Wensing CJG and Rommerts FFG (1992) Hormone-induced resistance of rat Leydig cells to the cytotoxic effects of ethane-1,2-dimethane sulphonate Journal of Endocrinology 134 85-90

Teerds KJ, de Boer-Brouwer $\mathbf{M}$, Dorrington JH, Balvers $\mathbf{M}$ and Ivell $\mathbf{R}$ (1999) Identification of markers for precursor and Leydig cell differentiation in the adult rat testis following ethane dimethyl sulphonate administration Biology of Reproduction 60 1437-1445

Williams TD, Dawson A, Nicholls TJ and Goldsmith AR (1987a) Reproductive endocrinology of free-living nestlings and juvenile starlings, Sturnus vulgaris; an altricial species Journal of Zoology (London) 212 619-628

Williams TD, Dawson A, Nichols TJ and Goldsmith AR (1987b) Short days induce premature reproductive maturation in juvenile starlings, Sturnus vulgaris. Journal of Reproduction and Fertility $80327-333$

Woods JE and Domm LV (1966) A histochemical identification of the androgen-producing cells in the gonads of the domestic fowl and albino rat General and Comparative Endocrinology 7 559-570

Woolveridge I, de Boer-Brouwer M, Taylor MF, Teerds KJ and Wu FCW (1999) Apoptosis in the rat spermatogenic epithelium following androgen withdrawal: changes in apoptosis-related genes Biology of Reproduction $60461-470$

Received 29 June 2001.

First decision 21 August 2001.

Revised manuscript received 14 November 2001.

Accepted 12 December 2001. 